\title{
Treatment of Leachate from the Technical Landfill Centre Aïn Defla (Algeria) by Oxidation and Biosorption Process
}

\author{
B. Feraoun, ${ }^{a}$ A. -E. Belhadj, K. Otmanine, ${ }^{\text {b. }}$ and M. Hammoudic \\ a Biomaterials and Transport Phenomena Laboratory (LBMPT), Yahia Fares University, \\ Department of Chemical Engineering and Environment, Médéa, 26 000, Algeria \\ b Bioressources Naturelles Locales LBRN, Hassiba Benbouali University of Chlef, Faculty of \\ Technology, Department of Process Engineering, Chlef, Algeria \\ c Biomaterials and Transport Phenomena Laboratory (LBMPT), Yahia Fares University, \\ Department of Chemical Engineering and Environment, Experimental Biology and \\ Pharmacology Team, Médéa, 26 000, Algeria
}

https://doi.org/10.15255/KUI.2020.075

KUI-43/2021

Original scientific paper

Received November 22, 2020

Accepted April 6, 2021

\begin{abstract}
The aim of this study was the treatment of leachate from the Technical Landfill Centre Aïn Defla in Algeria, which presents a serious threat to the environment. Elimination of organic matter (expressed as chemical oxygen demand (COD) and biological oxygen demand $\left(\mathrm{BOD}_{5}\right)$ ), suspended matter $(\mathrm{SM})$, mineral matter (phosphates and ammoniacal nitrogen), and heavy metals (zinc and iron) were experimentally studied using the coupling of oxidation (OP) and biosorption processes (BS). The analysis results showed that the leachate studied at $\mathrm{pH} 8.8$ was very loaded in organic matter (turbidity of $553 \mathrm{NTU}, \mathrm{SM}=820 \mathrm{mgl} \mathrm{I}^{-1}$, $\mathrm{COD}=9669 \mathrm{mg} \mathrm{O}_{2} \mathrm{I}^{-1}$, and $\left.\mathrm{BOD}_{5}=8875 \mathrm{mg} \mathrm{O}_{2} \mathrm{I}^{-1}\right)$, in salts $\left(E C=19.4 \mathrm{mS} \mathrm{cm}^{-1}\right)$, in ammoniacal nitrogen $\left(2027 \mathrm{mgl} \mathrm{I}^{-1}\right)$, in phosphates $\left(22.9 \mathrm{mg} \mathrm{l}^{-1}\right)$, and in sulphates $\left(750 \mathrm{mg} \mathrm{l}^{-1}\right)$. It also contained significant amounts of heavy metals, notably zinc $\left(4.21 \mathrm{mg} \mathrm{l}^{-1}\right)$ and iron $\left(47.5 \mathrm{mg} \mathrm{l}^{-1}\right)$. The evolution of the physicochemical parameters during the treatment showed that, under the optimal conditions $\left(T=45^{\circ} \mathrm{C},\left[\mathrm{H}_{2} \mathrm{O}_{2}\right]=1.6 \mathrm{moll}^{-1}\right.$, volume fraction $\varphi\left(\mathrm{H}_{2} \mathrm{O}_{2}\right)=5 \%$, and $\left.\left[\mathrm{Fe}^{3+}\right]=0.5 \mathrm{mmol} \mathrm{I}^{-1}\right)$, the reduction in $\mathrm{COD}$ was about $99 \%$, the reduction in $\mathrm{BOD}_{5}$ was $100 \%$, the elimination of colloidal particles (SM) could reach $95 \%$, reduction in phosphates was $78 \%$, reduction in ammonium was $98 \%$, reduction in sulphates was $96 \%$, reduction in zinc was $92 \%$, and the reduction in iron was $98 \%$.
\end{abstract}

\section{Keywords}

Leachate, landfill, oxidation process, biosorption

\section{Introduction}

Technical landfills present a prime solution for waste storage. However, this option creates different problems, among which is the production of leachate, an effluent with a high polluting potential (high organic matter content and salinity), which poses a serious threat to the environment and human health. ${ }^{1,2}$

Their structure differs from one landfill to another based on the nature of the waste, age of the traps, age of the leachate, climatic circumstances, and site topography. ${ }^{3,4}$

The literature recognises three kinds of leachate: youthful leachates defined by the elevated and relatively biodegradable organic burden; intermediate leachates with reduced organic burden, and stable leachates consisting mainly of humic substances immune to biodegradation. Because of their variable structure over time, they must undergo varying procedures before being discharged into the recipient setting. ${ }^{5}$

The Technical Landfill Centre (TLC) Aïn Defla was commissioned in 2013. Approximately 41 Mt per year of household waste was entering the TLC Aïn Defla and the major-

* Corresponding author: Khaled Otmanine

Email: otmaninegpp@gmail.com ity consisted of a high organic load. In the first four months of 2019, the volume of leachate produced was $20 \mathrm{~m}^{3}$ per day and the volume stored in three lagoons at the end of 2019 was $80,000 \mathrm{~m}^{3}{ }^{6}$

In order to decrease the leachate composition, a scheme of recirculation and suction was set up, but efficiency remained very low. The physicochemical analyses performed on these leachates enabled the determination of their size and chemical composition, particularly their degree of contamination. ${ }^{3,4}$

Leachate is composed of $83 \%$ to $92 \%$ of water, $4 \%$ to $16 \%$ of organic compounds, and $1 \%$ to $20 \%$ of inorganic compounds. The colour of the scrap varies from white to dark brown. It includes elevated levels of hanging fluid. In addition to visual annoyance and unpleasant odours, the elevated organic burden of leachate kills fauna and aquatic vegetation by capturing dissolved oxygen that has damaging impact on water, soil, micro-organisms, and crops. $^{3,4}$

More than 20 processes or technologies applicable for treatment of leachate have been identified in scientific works. In most instances, these are basic or combined operations that have been conducted on a laboratory or pilot-plant scale with no real industrial projection. The present methods were defined as the most widely used and 

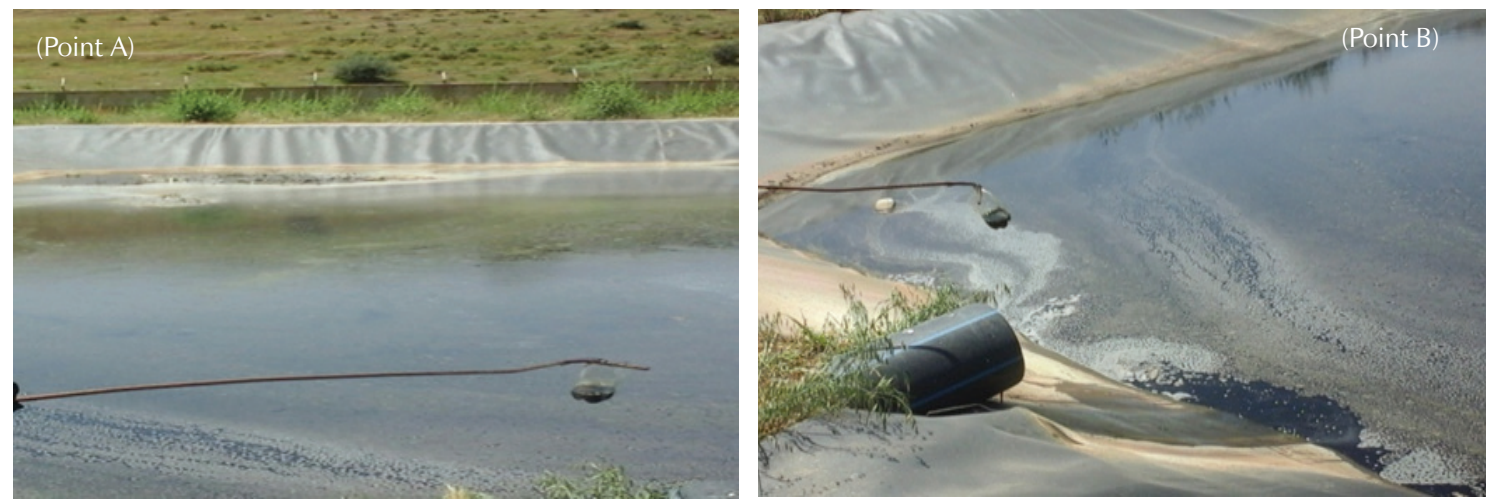

Fig. 1 - Location of leachate sampling point

they can possibly be applied. These methods of treatment can be categorised by the technique used: ${ }^{3}$

- thermal - by evaporation, incineration,

- physicochemical - by filtration/ultrafiltration, ozonation, and coagulation,

- biological - by anaerobic and aerobic treatment. ${ }^{7}$

However, when it comes to treating the (mature) leachate with a high proportion of bio-refractory compounds, these technologies face some limitations. ${ }^{8}$ To overcome this problem, in order to increase the efficiency of purification, biofiltration (BF) can be coupled with other non-biological systems. ${ }^{9}$ In recent studies, many combinations have been tested, including BF and chemical coagulation, ${ }^{10,11}$ BF membrane technologies, ${ }^{12,13}$ bio-process (BP) and advanced oxidising processes, ${ }^{14,15} \mathrm{BF}$ and electrochemical processes, etc. ${ }^{16}$ Among these combinations, the homogeneous advanced oxidation process (HAOP) could be an interesting approach to support a biological system in a treatment process. ${ }^{17,18}$

The concept of HAOP comprises the generation of free radicals, very unstable species of oxidising substances that can degrade chemical compounds found in effluents. ${ }^{19,20}$ In chemicals that are hard to degrade, the Fenton-reaction has shown excellent outcomes. In this response, the following sequence of Fenton reactions was suggested, where hydrogen peroxide $\left(\mathrm{H}_{2} \mathrm{O}_{2}\right)$ is used effectively in place of ferrous salts for leachate:

$$
\begin{gathered}
\mathrm{Fe}^{2+}+\mathrm{H}_{2} \mathrm{O}_{2} \rightarrow \mathrm{Fe}^{3+}+\mathrm{HO} \bullet+\mathrm{HO}^{-} \\
\mathrm{HO} \bullet+\mathrm{H}_{2} \mathrm{O}_{2} \rightarrow \mathrm{HOO} \bullet+\mathrm{H}_{2} \mathrm{O} \\
\mathrm{Fe}^{3+}+\mathrm{HOO} \bullet \rightarrow \mathrm{Fe}^{2+}+\mathrm{H}^{+}+\mathrm{O}_{2} \\
\mathrm{Fe}^{2+}+\mathrm{HOO} \bullet \rightarrow \mathrm{Fe}^{3+}+\mathrm{HOO}^{-}
\end{gathered}
$$

The initial response is the overall Fenton reaction. In order to obtain the important quantities of radical $\mathrm{HO} \bullet$, the cycle must be optimised. Ferric ion $\left(\mathrm{Fe}^{3+}\right)$ and a range of oxidising species $\left(\mathrm{HO} \bullet, \mathrm{HOO} \bullet, \mathrm{HOO}^{-}\right.$, and $\left.\mathrm{H}_{2} \mathrm{O}_{2}\right)$ will be available. Furthermore, the ferric ions $\left(\mathrm{Fe}^{3+}\right)$ will interact with the hydroperoxide radicals $(\mathrm{HOO} \bullet)$ and will be reduced to $\mathrm{Fe}^{2+}$. However, $\mathrm{Fe}^{2+}$ will react with extra $\mathrm{HOO} \bullet$ to generate $\mathrm{Fe}^{3+} .21,22$
As seen during the Fenton reaction, the hydrated ferrous oxide will eventually be formed. For the Fenton reaction to be effective, the $\mathrm{pH}$ must be adjusted between 2 and 4. The primary benefits of HAOP are small sludge output contrary to the chemical products. ${ }^{19,20}$

A BF method can be used to achieve the extra suppression of contaminants following the advanced oxide treatment. The frequently used absorber is active carbon (AC), whose effectiveness is high (20\%). However, the impact from palm oil and empty fruits on extraction of phenol has been explored under various production circumstances for active carbon. These parameters include temperature, ignition moment, and speed of $\mathrm{CO}_{2}$ stream..$^{19,20}$

Activated charcoal is made from various fresh products, such as coconut marrow activated with $\mathrm{ZnCl}_{2}$, pecan and caps tile nuts shells, jackfruit bark, oak bowl pulp, $\mathrm{H}_{3} \mathrm{PO}_{4}$ acid treatment, and palm seeds shell. Coffee grounds and sawdust have been used as adsorbents because of their structure and characteristics. ${ }^{19-30}$

The main objective of this study was to optimise the conditions for the elimination of organic and nitrogenous matter by coupling the oxidation process (OP) with biosorption (BS). The experiments were carried out on the leachate from the TLC Aïn Defla. After characterisation of the leachate, treatment trials made it possible to determine the optimal treatment doses. Finally, a process coupling performance analysis was conducted.

\section{Materials and methods}

\subsection{Sampling and characterisation of leachate}

Samples of coarse leachate were acquired from TLC Ain Defla, Algeria. The leachate was collected and analysed between $1 / 9 / 2018$ and $1 / 3 / 2019$, and stored at $4{ }^{\circ} \mathrm{C}$ until its use within $48 \mathrm{~h}$ or as a note that the climate in this area is semi-arid.

The multi-parameter water analyser model HI19629 (HANNA Instruments, USA) was used to measure the electrical conductivity (EC), dissolved solids (DS), $\mathrm{pH}$, and temperature in situ. A PPOxiTop ${ }^{\circledR}$ A6 thermostat was 
used to measure BOD. The COD was evaluated using a HI839800 reactor model (HANNA Instruments, USA) with sulphochromic oxidation. Atomic absorption spectrometer (AAS) 700 was used to determine the heavy metals $\mathrm{Al}, \mathrm{Ca}$, $\mathrm{Cd}, \mathrm{Cu}, \mathrm{Pb}, \mathrm{Fe}, \mathrm{K}$, and $\mathrm{Mn}$. Turbidity was measured by the turbidity meter model HI88703 (HANNA Instruments, USA) for nephelometric turbidity units (NTU).

These leachate samples were forwarded in iceboxes to the Environment and Cleanliness Laboratory, Khemis Miliana Aïn Defla, Sustainable Development Laboratory of the Region, University of Djilali Bounaama Khemis Miliana, Microbiology Laboratory and the Materials Laboratory of Yahia Farès, University of Médéa, with respect to the circumstances of conservation needed by the norms in order to slow down the biological, chemical, and physical processes.

\subsection{Oxidation of the leachate}

\subsubsection{Determination of the optimal oxidation temperature}

To ensure the complete homogenisation of the reactionary milieu, leachate was poured into volumetric glaze and shaken by a magnetic agitator for $30 \mathrm{~min}$. The reactor thermostat was started and the set-up temperature was adjusted to the desired value. The reactor temperature was set to the following temperatures: $40,45,50,55$, and $60{ }^{\circ} \mathrm{C}$. The $\mathrm{pH}$ of leachate was raised to 2.6 with a few drops of $10 \%$ $\mathrm{H}_{2} \mathrm{SO}_{4}$ (for the homogeneous Fenton response the optimum $\mathrm{pH}$ is around this level). After stabilisation of reactor temperature, the first sample was drawn at time zero with the addition of hydrogen peroxide to start a method for oxidation. To monitor turbidity reduction, regular samples were obtained. About $3 \mathrm{ml}$ of fluid samples were taken during specified periods (after 15, 30, 45, 60, 75, 90, 115, and $120 \mathrm{~min}$ ) during $2 \mathrm{~h}$ of oxidation.

\subsubsection{Determination of the optimal concentration of $\mathrm{H}_{2} \mathrm{O}_{2}$}

In this part, the $\mathrm{pH}$ of liquid was decreased to 2.6 and the temperature was set at $45^{\circ} \mathrm{C}$ because this temperature gave a reduction of $50 \%$. In this process, the amount of oxidising agent of varying degrees was used (0.8, 1.6, 2.4, and $3.2 \mathrm{moll}^{-1}$ ). A sample was taken every $15 \mathrm{~min}$ for $2 \mathrm{~h}$.

\subsubsection{Determination of the optimal volume fractions of $\mathrm{H}_{2} \mathrm{O}_{2}$}

The following processes are quite comparable to the past two. The reactor contained the same concentration of $\mathrm{H}_{2} \mathrm{O}_{2}$, which was equivalent to $1.6 \mathrm{moll}^{-1}$. The investigated hydrogen peroxide volume fractions $(\varphi)$ were $1,2.5,5$, and $10 \%$.

\subsubsection{Effect of soluble catalyst on treatment}

The strong catalytic agent to study was Fe(III). Therefore, under the current working conditions, it was planned to examine the impact of metal oxide $-\mathrm{FeCl}_{3} \cdot 6 \mathrm{H}_{2} \mathrm{O}(99 \%)$ which is the source of $\mathrm{Fe}(\mathrm{III})$.

The experiment was carried out under optimal conditions, at $45{ }^{\circ} \mathrm{C}$ and $\mathrm{pH} 2.6$, with a volume fraction of $5 \%$ of $\mathrm{H}_{2} \mathrm{O}_{2}$ at concentration of $1.6 \mathrm{moll}^{-1}$.

\subsubsection{Effect of the ratio $\mathrm{R}=\left[\mathrm{H}_{2} \mathrm{O}_{2}\right] /\left[\mathrm{Fe}^{3+}\right]$ on processing}

In the attempt to optimise the operating circumstances of leachate oxidation, the proportions between the oxidising agent and the catalyst were investigated. These proportions were $R=10$ to $R=60$. The operating conditions were $T=45{ }^{\circ} \mathrm{C},\left[\mathrm{H}_{2} \mathrm{O}_{2}\right]=1.6 \mathrm{moll}^{-1}, \mathrm{pH}=2.6$, and $\left[\mathrm{Fe}^{3+}\right]=0.5 \mathrm{mmoll}^{-1}$.

\subsection{Treatment of leachate with biomaterials}

Sand or activated carbon filtration or filter media are water filtration systems used to solve many problems in the treatment of liquid effluents. Each filter medium has a specific function in the liquid effluents treatment:

- Sand filters for the sediments.

- Coffee grounds and sawdust transformed into activated carbon to absorb chlorine and organic matter.

\subsubsection{Preparation of the constituents for biosorption column}

A - Sand: The sand was screened after drying in an oven at $150{ }^{\circ} \mathrm{C}$ for $24 \mathrm{~h}$. The diameter of the used particle ranged from 0.040 to $0.500 \mathrm{~mm}$.

$B$ - Sawdust: Sawdust or chips are scraps of material after wood is cut or formed. It was crushed and sieved after washing the scrub thoroughly with distilled water, and put in an oven at a temperature of $105^{\circ} \mathrm{C}$ for $24 \mathrm{~h}$. There were two kinds of particle magnitude chosen. The first one was between 0.2 and $1 \mathrm{~cm}$ in diameter. The second diameter was between 0.040 and $0.025 \mathrm{~cm}$. The resulting particles were cured in free air at $300{ }^{\circ} \mathrm{C}$ for $4 \mathrm{~h}$, and then treated for $1 \mathrm{~h}$ in sodium hydroxide $\left(3 \mathrm{~mol} \mathrm{I}^{-3}\right)$ baths, thoroughly washed out with distilled water, and dried for $2 \mathrm{~h}$ at $105{ }^{\circ} \mathrm{C}$.

C - Coffee grounds: After washing the coffee grounds of any impurities, they were baked at $300{ }^{\circ} \mathrm{C}$ for $4 \mathrm{~h}$ in open air. They were then washed in sodium hydroxide $\left(3 \mathrm{moll}^{-3}\right)$ baths, washed to a neutral $\mathrm{pH}$ with distilled water, and dried for $2 \mathrm{~h}$ at $105^{\circ} \mathrm{C}$.

$D$ - Peat: Peat is a mix between the Aïn Defla landfill pot soil and the water retrieved from the lagoon floor.

\subsubsection{Biosorption column}

The column was made of PVC, $150 \mathrm{~cm}$ high and $10 \mathrm{~cm}$ in diameter. The packing of the column was mainly composed of sawdust, sand, coffee grounds, and peat. These four components were arranged in five layers (Fig. 2). The 
column was formed from top to bottom as soot: a vacuum of $20 \%$ was maintained to ensure the atmospheric pressure on the leachate, and then a first course upper layer composed only of sawdust with a diameter between 0.2 and $1 \mathrm{~cm}$, which had the role of facilitating the passage of liquid and limiting clogging. The second layer was made up of $5 \%$ sand, $35 \%$ sawdust of diameter 0.04 to $0.25 \mathrm{~mm}, 35 \%$ coffee grounds, $20 \%$ peat, and $5 \%$ calcite by volume percentage. Calcite $\left(\mathrm{CaCO}_{3}\right)$ added to these layers made it possible both to stabilise the $\mathrm{pH}$ of the effluent thanks to the buffering capacity of carbonates, and to optimise nitrification with the availability of a mineral carbon source for the autotrophic bacteria responsible for the nitrification. To facilitate the percolation of the liquid in the filter medium, another $20-\mathrm{cm}$ layer of $50 \%$ sand and $50 \%$ wood chips with a diameter of 0.2 to $0.1 \mathrm{~cm}$ was placed between the second and fourth layer. The fourth layer was $50 \mathrm{~cm}$ high and composed of $50 \%$ sawdust with a diameter of 0.04 to $0.25 \mathrm{~mm}, 40 \%$ peat, $5 \%$ sand, and $5 \%$ calcite. The fifth layer was placed on $5-\mathrm{cm}$ high coffee grounds, and finished with a $5-\mathrm{cm}$ layer of green beads to allow the filtrate to drain.

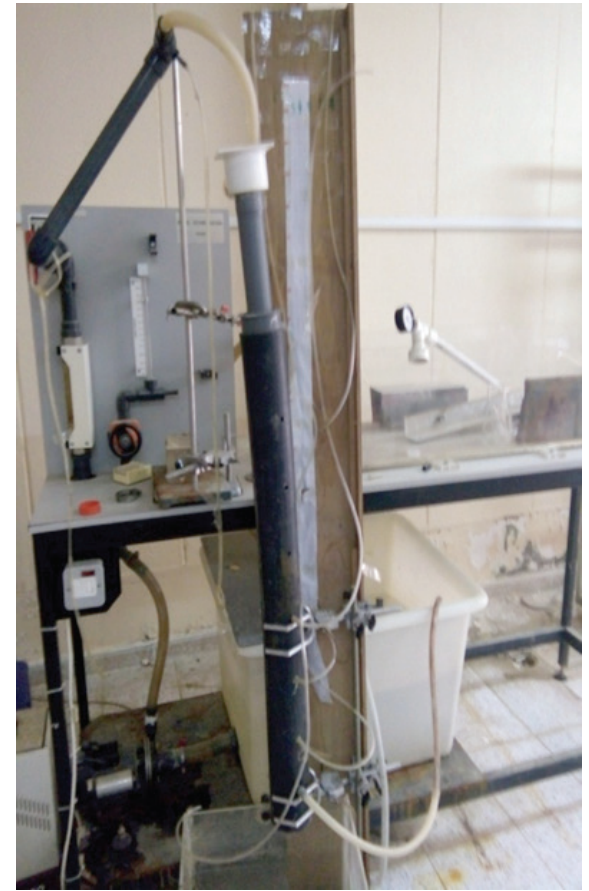

Fig. 2 - Biosorption column

\section{Results and discussion}

\subsection{Characterisation of the leachate of Aïn Defla landfill}

Every landfill has a specific chemical composition of leachate. This differs widely depending on the nature and age of the deposit, waste type and decomposition, the method of deposit, the nature of the landfill, the climate, etc. $3,4,31$
Table 1 - Average values of the physicochemical parameters of the leachate from TLC Aïn Defla

\begin{tabular}{|c|c|c|}
\hline Parameter & Unit & Value \\
\hline $\mathrm{pH}$ & - & 8.8 \\
\hline total dissolved solids (TDS) & $\left.m g\right|^{-1}$ & 10 \\
\hline$E C$ & $\mathrm{mS} \mathrm{cm}^{-1}$ & 19.4 \\
\hline turbidity & NTU & 533 \\
\hline SM & $\mathrm{mgl}^{-1}$ & 820 \\
\hline $\mathrm{O}_{2}$ dissolved & $\mathrm{mgl}^{-1}$ & 3.12 \\
\hline $\mathrm{BOD}_{5}$ & $\mathrm{mg} \mathrm{O}_{2} \mathrm{I}^{-1}$ & 8875 \\
\hline COD & $\mathrm{mg} \mathrm{O}_{2} \mathrm{I}^{-1}$ & 9669 \\
\hline $\mathrm{BOD}_{5} / \mathrm{COD}$ & - & 0.91 \\
\hline $\mathrm{NH}_{4}^{+}$ & $\mathrm{mgl}^{-1}$ & 2027 \\
\hline $\mathrm{NO}_{2}^{-}$ & $\left.m g\right|^{-1}$ & 2.73 \\
\hline $\mathrm{NO}_{3}^{-}$ & $\left.m g\right|^{-1}$ & 5021 \\
\hline $\mathrm{PO}_{4}{ }^{3-}$ & $\left.m g\right|^{-1}$ & 22.9 \\
\hline $\mathrm{SO}_{4}{ }^{2-}$ & $\mathrm{mgl}^{-1}$ & 750 \\
\hline $\mathrm{Ca}^{2+}$ & $\left.m g\right|^{-1}$ & 12.80 \\
\hline $\mathrm{Mg}^{2+}$ & $\mathrm{mgl}^{-1}$ & 350 \\
\hline $\mathrm{K}^{+}$ & $\mathrm{mgl}^{-1}$ & 2.85 \\
\hline $\mathrm{Na}^{+}$ & $\left.m g\right|^{-1}$ & 2.5 \\
\hline As & $\left.m g\right|^{-1}$ & 0.19 \\
\hline $\mathrm{Cd}$ & $\mathrm{mgl}^{-1}$ & 1.25 \\
\hline $\mathrm{Cr}$ & $\left.m g\right|^{-1}$ & 2.0 \\
\hline $\mathrm{Cu}$ & $\mathrm{mgl}^{-1}$ & 1.45 \\
\hline Fe & $\mathrm{mgl}^{-1}$ & 47.5 \\
\hline $\mathrm{Mn}$ & $\mathrm{mgl}^{-1}$ & 1.10 \\
\hline $\mathrm{Ni}$ & $\mathrm{mgl}^{-1}$ & 3.43 \\
\hline $\mathrm{Pb}$ & $\mathrm{mgl}^{-1}$ & 0.9 \\
\hline $\mathrm{Zn}$ & $\mathrm{mgl}^{-1}$ & 4.21 \\
\hline
\end{tabular}

Table 1 presents the results of physicochemical analysis carried out during the characterisation of the raw leachate from the Aïn Defla landfill. For the different parameters analysed in leachate, the highest level needed refers to the existing Algerian legislation on the release of industrial liquid effluents, since discharge juices or leachates are often equivalent to the complicated agricultural discharges of organic and inorganic pollutants. ${ }^{13}$

Presuming that the release or juices of leachate can be compared to the complicated manufacturing releases comprising both organic and inorganic contaminants, the previously found sand results of physicochemical parameters of Aïn Defla landfill coarse leachate with a faecaloid odour release are presented in Table 1.

Ain Defla landfill leachate is essential. The mean pH-value registered is 8.8. The characteristic of acidic conditions in the initial aerobic waste degradation phase is generally increased in order to solubilize chemical elements (hydrox- 
ide acids and carbonate species) and to decrease the waste sorption capacities. However, the $\mathrm{pH}$ is essential in this situation, probably because of the recycling system between the lagoons and lockers.

The analysis of the results showed that the leachate was rich in natural material and that elevated $\mathrm{BOD}_{5}$ and $\mathrm{COD}$ numbers (8875 $\mathrm{mg} \mathrm{O}_{2} \mathrm{I}^{-1}, 9669 \mathrm{mg} \mathrm{O}_{2} \mathrm{I}^{-1}$, respectively) were true. COD in the leachate exceeded appropriate values. On average, it was more than 80 times higher than the prescribed level of Algerian industrial discharges ${ }^{1}$, which is about $120 \mathrm{mg} \mathrm{O}_{2} \mathrm{I}^{-1}$, with regard to the $\mathrm{BOD}_{5}$, detected in the various leachate samples after 5 days of incubation, thus exceeding the approved norm by approximately $35 \mathrm{mg} \mathrm{O}_{2} \mathrm{I}^{-1}$. However, the real level of $\mathrm{BOD}_{5}$ continued to be superior to the actual figures since the substrate was packed with toxic materials. Furthermore, the $\mathrm{BOD}_{5} / \mathrm{COD}$ proportion is the indication of organic matter biodegradation and leachate maturation. ${ }^{32,33}$ Therefore, for young rejects from which the biological activity corresponds to the acid phase of anaerobic degradation, this ratio reaches the value of 0.83 . It was down to 0.05 for ancient sites, where the final phase of methanogens fermentation was achieved. The decreases in COD and specifically in $\mathrm{BOD}_{5}$ characterise this formation phase in our situation. The TLC Aïn Defla leachate appeared to be in the acidic phase $\left(\mathrm{BOD}_{5} / \mathrm{COD}=0.91\right) .{ }^{32-34}$

In fact, the average $E C$ was $19.4 \mathrm{mS} \mathrm{cm}^{-1}$, indicating strong mineralisation of TLC Aïn Defla leachate. This mineralisation was mainly attributable to the following parameters: ammonium (2027 $\mathrm{mg} \mathrm{l}^{-1}$ ), phosphate (22.9 $\mathrm{mg} \mathrm{l}^{-1}$ ), sulphate $\left(750 \mathrm{mg}^{-1}\right)$, potassium $\left(2.85 \mathrm{mg} \mathrm{l}^{-1}\right)$, and sodium $\left(2.5 \mathrm{mg} \mathrm{l}^{-1}\right)$. Dissolved solids (DS $=10 \mathrm{mg} \mathrm{l}^{-1}$ ) refer to all the minerals, salts, metals, cations or anions dissolved in the water. This includes anything present in the water other than $\mathrm{H}_{2} \mathrm{O}$ molecules, including suspended solids. Turbidity of leachate was significant. This was because the sun had not penetrated the algae that show biological imbalance, confirmed by the elevated level of suspended material (SM).

For nitrites (Table 1), it was noticed that, on several occasions, the quantity passed the obtained level. The existence of nitrites showed the identification of our samples as comparable to industrial discharges.

The most responsible ingredients of leachate smell are sulphates, and in this model, they were concentrated at $750 \mathrm{mgl}^{-1} .{ }^{35}$ The sulphates were then reduced to sulphides in the form of $\mathrm{H}_{2} \mathrm{~S}$, the gas responsible for bad smells emanating from the landfill. ${ }^{35}$

The evolution of the levels of salt, potassium, calcium, and magnesium in leachate, like most metallic components (Table 1), is linked to the quantity of organic matter dissolved. ${ }^{36}$ Indeed, the high concentrations of the magnesium element is due to the fact that, during the dry period, the organic matter responsible for the complexity of these elements is very low.
Table 1 shows the heavy metal composition of the leachate. The metal load in these percolas was significant. Iron was the metal in larger amounts with concentration levels of $47.5 \mathrm{mgl}^{-1}$, which is compatible with the bibliographic data. The metal products of the waste dump are primarily composed of iron. ${ }^{33}$

Toxic metals were present in relatively low concentrations (nickel - $3.43 \mathrm{mg} \mathrm{l}^{-1}$, cadmium - $1.25 \mathrm{mg} \mathrm{I}^{-1}$, copper - $1.45 \mathrm{mg} \mathrm{l}^{-1}$ ), and they were lower than leachate generated by other landfills. ${ }^{18,37}$ The household waste treatment scheme positioned before the container was responsible for these values, but most heavy metals were stuck in the waste. ${ }^{34,35}$ The following rates were classified: $\mathrm{Fe}>\mathrm{Zn}>\mathrm{Ni}>\mathrm{Cu}$ and $\mathrm{Mn}>\mathrm{Cd}>\mathrm{Cr}>\mathrm{Pb}>$ As in increasing orders. Therefore, in these leachates, there was an obstruction of microbial development and interference with the competitive $\mathrm{BOD}_{5}$ outcomes by the existence of heavy metals.

\subsection{Study of the oxidation process}

The oxidation study revealed that the sophisticated oxidation method under consideration was dependent on the HAOP. What treatment of this leachate was needed to prevent any type of environmental pollution?

\subsubsection{Temperature effects}

The turbidity evolution of crude leachate alone (witness 1 ) with oxidising agent (witness 2), and with oxidising agent plus $\mathrm{pH}=2.6$ adjustment (sample) was monitored during 120 min corresponding to the standard reaction time (Fig. 3).

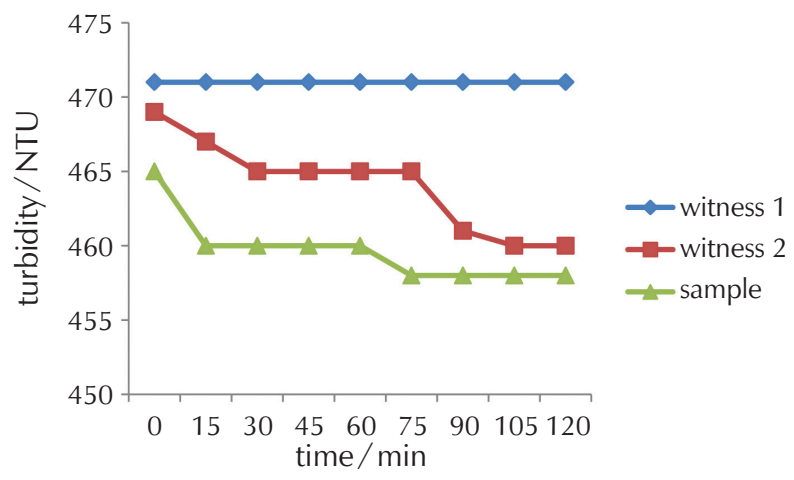

Fig. 3 - Stability of turbidity at $20^{\circ} \mathrm{C}$

The results showed that $\mathrm{H}_{2} \mathrm{O}_{2}$ hardly decreased leachate during the reaction time at $20{ }^{\circ} \mathrm{C}$ (less than $3 \%$ transformation within $120 \mathrm{~min}$ ). Fig. 4 shows that turbidity had decreased with time at various temperature conditions ( $T$ from 40 to $60{ }^{\circ} \mathrm{C}$ ). 


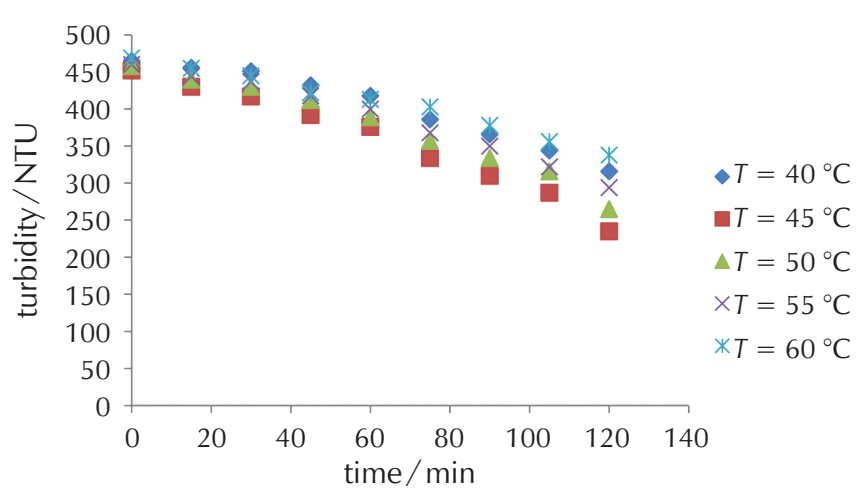

Fig. 4 - Influence of temperature on turbidity

At the start of responses, turbidity usually amounted to about 460 NTU and above, and the study was carried out within a $120-$ min period. Following the increase in temperature $\left(40,45,50,55\right.$, and $\left.60^{\circ} \mathrm{C}\right)$, it was noted that the impact of $\mathrm{H}_{2} \mathrm{O}_{2}$ in acidic environment $(\mathrm{pH}=2.6)$ became more efficient than the findings in the neuter environment $(\mathrm{pH}=7)$.

The leachate turbidity from the TLC Aïn Defla had a value of $465 \pm 5$ NTU. After studying the influence of temperature on the turbidity, it was found that the value of 235 NTU was reached with a yield of $50 \%$. Once the temperature rises, it starts to demineralise because of the degradation of hydrogen peroxide at high temperature.

\subsubsection{Determination of the optimal volume fraction of $\mathrm{H}_{2} \mathrm{O}_{2}$}

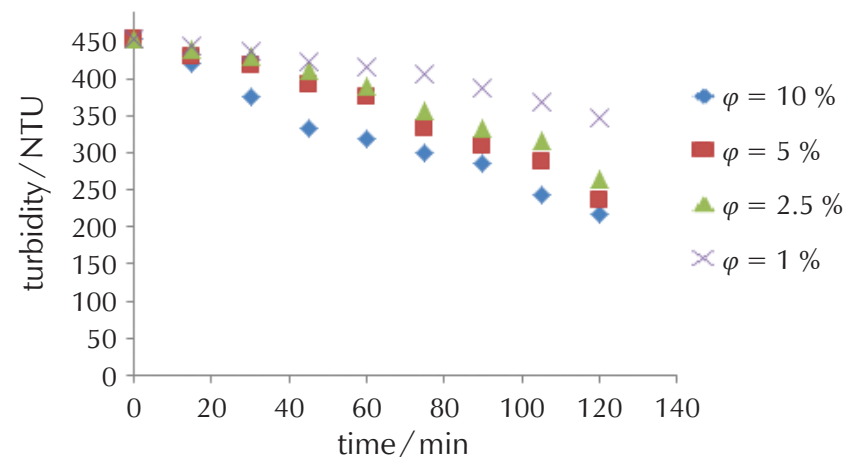

Fig. 5 - Influence of $\mathrm{H}_{2} \mathrm{O}_{2}$ volume fraction on turbidity

\subsubsection{Determination of the optimal concentration of $\mathrm{H}_{2} \mathrm{O}_{2}$}

According to the obvious first-order kinetics, when a leachate solution is subjected to HAOP, original turbidity reduces linearly with a moment. After $2 \mathrm{~h}$ of treatment, a decrease frequency for an $\mathrm{H}_{2} \mathrm{O}_{2}$ level was more than $61 \%$, equivalent to $1.6 \mathrm{~mol} \mathrm{I}^{-1}$ (Fig. 5). Fig. 6 also demonstrates the turbidity image. Therefore, low concentration of $\mathrm{H}_{2} \mathrm{O}_{2}$ $\left(0.8 \mathrm{moll}^{-1}\right)$ led to a reduction in reaction rate.

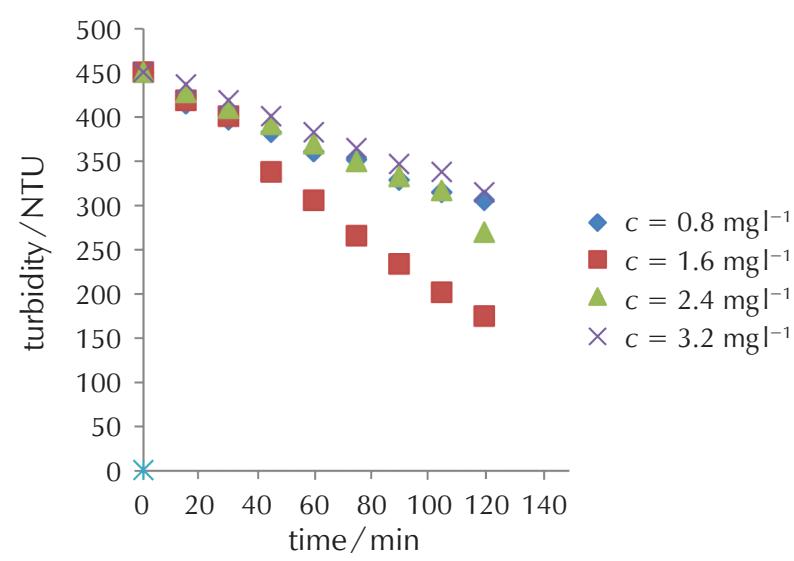

Fig. 6 - Influence of $\mathrm{H}_{2} \mathrm{O}_{2}$ concentration on turbidity

According to Eq. 2, at high concentrations, the hydroxyl radicals preferentially react with the hydrogen peroxides of the leachate.

\subsubsection{Effect of soluble catalyst $\left(\mathrm{Fe}^{3+}\right)$ on the treatment}

For removing leachate turbidity, Fig. 7 shows the initial $\mathrm{Fe}^{3+}$ level at varying concentrations.

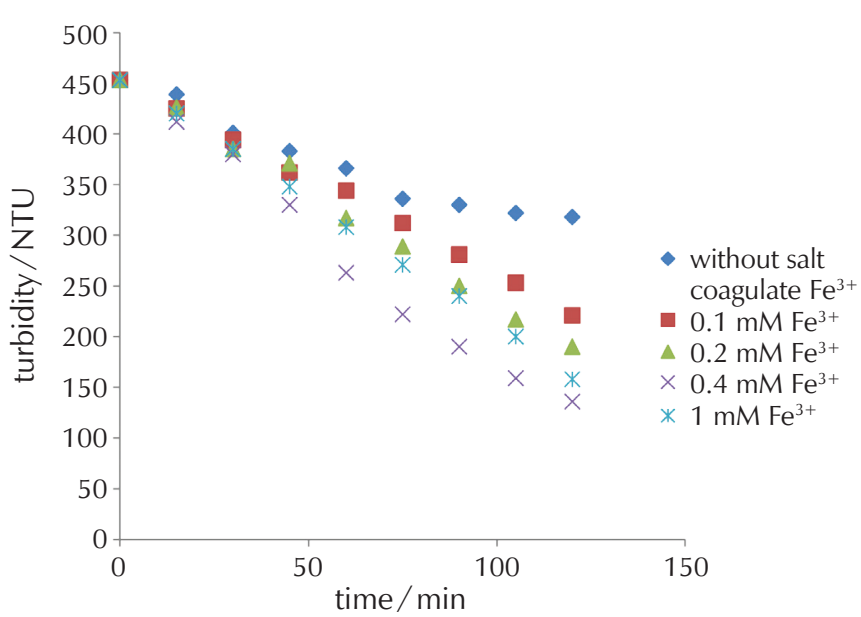

Fig. 7 - Influence of catalyst $\mathrm{Fe}^{3+}$ concentration on turbidity

Fig. 7 shows that adding the ferric ions improved the system's effectiveness, and resulted in the rise of the initial catalyst concentration from 0.1 to $0.5 \mathrm{mmol} \mathrm{I}^{-1}$ (Eqs. (5) and (6)): 38,39

$$
\begin{aligned}
\mathrm{Fe}^{3+}+\mathrm{H}_{2} \mathrm{O}_{2} & \rightarrow \mathrm{Fe}-\mathrm{OOH}^{2+}+\mathrm{H}^{+} \\
\mathrm{Fe}-\mathrm{OOH}^{2+} & \rightarrow \mathrm{HOO} \cdot+\mathrm{Fe}^{2+}
\end{aligned}
$$


Table 2 - Performance of leachate treatment with OP. Conditions: $T=45{ }^{\circ} \mathrm{C},\left[\mathrm{H}_{2} \mathrm{O}_{2}\right]=1.6 \mathrm{moll}^{-1},\left[\mathrm{Fe}^{3+}\right]=0.5 \mathrm{mmoll} \mathrm{I}^{-1}, R=40$.

\begin{tabular}{c|c|c|c|c|c|c|c|c|c|c|c|c|c}
\hline $\begin{array}{c}\text { Characteristics } \\
\text { of leachate }\end{array}$ & $\mathrm{pH}$ & $\mathrm{BOD}_{5}$ & $\mathrm{COD}$ & $\mathrm{EC}$ & Turbidity & $\mathrm{SM}$ & $\mathrm{NH}_{4}^{+}$ & $\mathrm{NO}_{2}^{-}$ & $\mathrm{NO}_{3}^{-}$ & $\mathrm{PO}_{4}^{3-}$ & $\mathrm{Ca}^{2+}$ & $\mathrm{Mg}^{2+}$ & $\mathrm{Fe}^{2}$ \\
\hline $\begin{array}{c}\text { unit } \\
\text { before } \\
\text { treatment }\end{array}$ & 8.8 & 8875 & 9669 & 19.4 & 533 & 820 & 2027 & 2.73 & 5021 & 22.9 & 12.80 & 350 & 47.5 \\
\hline \begin{tabular}{c} 
after treatment \\
\hline \begin{tabular}{c} 
output $\%$ \\
\hline
\end{tabular}
\end{tabular} & 6.39 & 0 & 1933.8 & 0.024 & 53.3 & 235 & 1479 & 1.52 & 1300 & 5.04 & 1.64 & 27.94 & 3.25 \\
\hline
\end{tabular}

\subsubsection{Influence of the ratio $R=\left[\mathrm{H}_{2} \mathrm{O}_{2}\right] /\left[\mathrm{Fe}^{3+}\right]$}

An experiment was carried out in order to determine the effect of the ratio $R=\left[\mathrm{H}_{2} \mathrm{O}_{2}\right] /\left[\mathrm{Fe}^{3+}\right]$ on leachate mineralisation as a function of time. Fig. 8 shows the results obtained by the Fenton process.

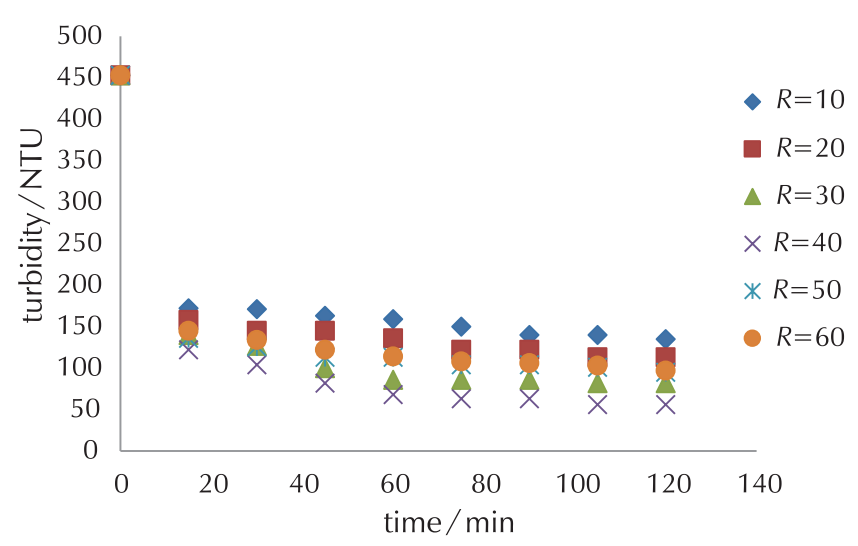

Fig. 8 - Assessment of turbidity during leachate mineralisation as a function of time for variable $R$ values for $\left[\mathrm{Fe}^{3+}\right]=0.5 \mathrm{mmoll}^{-1}$

Fig. 8 shows the evolution of turbidity during the leachate mineralisation as a function of time for $R$-ratio values ranging from 10 to 60 at a fixed concentration of $\mathrm{Fe}^{3+}=0.5 \mathrm{mmoll}^{-1}$.

The achieved findings indicated that the kinetics of mineralisation improved when $R$ increased. The level of leachate mineralisation in aspects of turbidity reduction increased quickly when $R$ increased from 10 to 40 (from $65 \%$ to $70 \%$ ) after 15 min of treatment. An $87 \%$ decrease in turbidity was achieved with $R=40$ after 120 min of treatment or almost complete elimination of the pollutant. This elevated mineralisation speed is related to the highly elevated radical hydroxyl formation (Eqs. (2) and (7)). For the Fenton reaction, ${ }^{40}$ an unnecessary rise in the amount of hydrogen peroxide ( $R=60$ ) may be a limiting factor in the Fenton process by consuming hydroxyl radicals according to Eqs. (2) and (7): ${ }^{36-41}$

$$
\mathrm{HOO} \bullet+\mathrm{HO} \bullet \rightarrow \mathrm{H}_{2} \mathrm{O}+\mathrm{O}_{2}
$$

Thus, when treated leachate by the Fenton process, $R=40$ was selected as the ideal value for the initial $\mathrm{Fe}^{3+}$ concentration $\left(0.5 \mathrm{mmol}^{-1}\right)$.

\subsubsection{OP performance on the leachate treatment of Ain Defla landfill}

Table 2 summarises the efficient removal of pollutants under the best operating conditions by the oxidation process $\left(45^{\circ} \mathrm{C},\left[\mathrm{H}_{2} \mathrm{O}_{2}\right]=1.6 \mathrm{moll}^{-1},\left[\mathrm{Fe}^{3+}\right]=0.5 \mathrm{mmol} \mathrm{I}{ }^{-1}\right.$, $R=40$ ). It should be noted that the values in this table are the average values obtained through analyses of leachate treated for feeding the biosorption unit under the optimum conditions. It can be seen that ammonia and siltation were insignificant. It was anticipated that OP would have poor ammonia suppression effectiveness. Other studies have also reported low ammonia removal in such landfill leachate treatment processes. ${ }^{42-44}$ After treatment, turbidity, colour, and metals had been efficiently removed. Ninety percent of the turbidity was withdrawn, likely because of the humic acid removal. In fact, despite the low proportion of humic acids in the waste leachate of landfills, it had a high colouring capacity. Metals, zinc, and iron, among others, have been effectively removed (87 \% Zn and $93 \% \mathrm{Fe}$ removed). ${ }^{42-44}$

The good removal of metals by the OP could be attributed to the precipitation and co-precipitation. The total phosphorus concentration was reduced by $78 \% .{ }^{45}$

Finally, in terms of $\mathrm{BOD}_{5}$, the biodegradable organic matter was eliminated $100 \%$ with a COD efficiency of $80 \%$ for the non-biodegradable organic matter. This is explained by the existence of non-oxidising compounds by OP, since it is hard to degrade carboxylic acids that were produced as intermediate. Some carboxylic acids, especially polyacids, form stable complexes with iron, which, in the absence of UV/Vis irradiation, inhibit the reaction by immobilising the metal in an inactive form (Eq. (8)): ${ }^{46}$

$$
\mathrm{Fe}^{3+}+\mathrm{nL} \rightarrow\left[\mathrm{FeL}_{n}\right]^{3+}
$$

where $\mathrm{L}$ are the mono- and dicarboxylic acids.

\subsubsection{Biosorption}

The biosorption unit was supplied with oxidised leachate or mineralised leachate previously acquired after adaptation to activate the microorganisms. 


\subsubsection{Elimination of organic matter}

The performance of biological treatment with regard to the removal of COD is shown in Fig. 9. Compared to the total removal of COD (99.87\%), BOD 5 was fully removed after treatment with OP. Following biological treatment, this value was maintained. The overall suppression of COD can be clarified by the presence of organic refractory content in leachate that had been adsorbed by the biosorption components and even biodegraded.

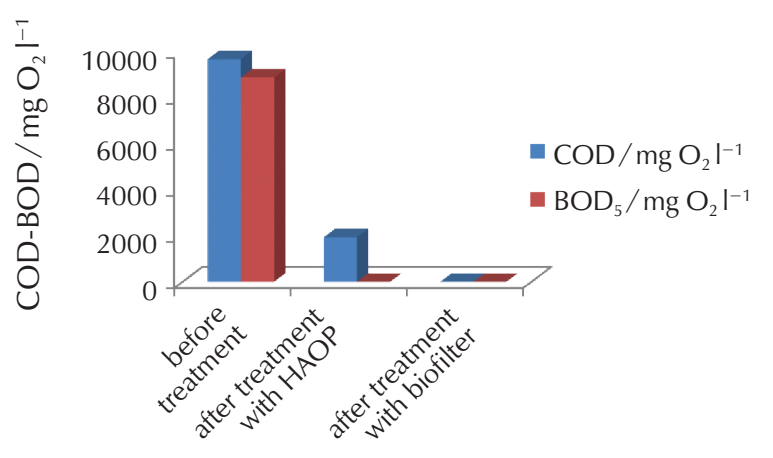

Fig. 9 - Assessment of organic matter before and after biosorption of mineralised leachate

Biosorption used to treat leachate from landfills, that were pre-treated under oxidation process, reported similar findings. ${ }^{47,48}$ After biosorption treatment of landfill leachate, a good rate of removal of the Hyl fraction and an insignificant rate of removal of humic substances (humic acid - HA and fulvic acid - FA) was observed.

\subsubsection{Removal of ammonia}

As stated in Table 5, at $27 \%$ of the initial load during OP, the removal of ammonia was low. Therefore, the primary task of treatment was the effective treatment of ammonia pollution. Average inlet flux of $500 \mathrm{ml} \mathrm{d}^{-1}$ was provided for the biosorption column. During the biological treatment, nitrogen variations were formed, as shown in Fig. 10. After biosorption, ammonia was almost entirely removed. The average outlet ammonia concentration was $0.68 \mathrm{mgl}^{-1}$, i.e., well below the Algerian standard norms. ${ }^{1}$ Nitrate $\left(\mathrm{NO}_{3}{ }^{-}\right)$and nitrite $\left(\mathrm{NO}_{2}^{-}\right)$levels were also monitored during the biosorption. The results were $99.57 \%$ and $99.96 \%$ elimination effectiveness. These results showed that nitrification was the principal mechanism for removing the ammonia from biosorption.

However, other biological and physicochemical events, such as $\mathrm{NH}_{3}-$ removal, assimilation, denitrification, and adsorption could also occur in a biosorption column. ${ }^{49,50}$

Despite the small phosphorus level and significant quantity of remaining SS acquired after OP treatment, the nitrification method was very efficient. Taking into account the sensitivity of nitrifying bacteria, inhibition of toxicity was a problem. These critical parameters cause the nitrification

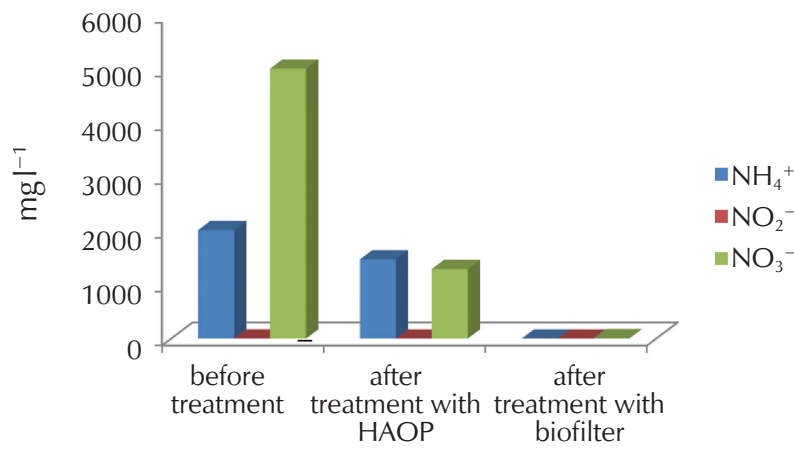

Fig. 10 - Evaluation of the nitrogenous material before and after biosorption of the mineralised leachate

method. With respect to phosphorus, the suitable item, the amount needed for microorganisms is a contentious topic.

The traditional proportion of C/N/P : 100/5/1 is usually recognised for suitable biosorption treatment. However, amid phosphorus deficiency, ${ }^{18}$ several researchers recorded excellent nitrogen extraction rates, describing the small phosphorus demand by the feasible biofilm recycling of phosphorus, arising from biomass decomposition. No negative effects on the nitrifying bacteria were found with respect to the effect of residual SM. This was in contradiction with some studies that argued that the ions present in OP's remaining SM had an adverse effect on the biological treatment..$^{51}$ In fact, metal ions can create dormant bonds and associations with certain bacterial enzymes and cause inhibition of their biological functions. ${ }^{52}$

Moreover, it has been stated that microorganisms are more susceptible to the toxicity of metals when they are in the shape of bare ions. On the other hand, metals' toxicity decreases when they are chelated by certain organic ligands such as humic substances. ${ }^{53}$ This may clarify the negligible effect of ions on the method of nitrification, according to this research using Aïn Defla landfill leachate.

\subsubsection{Biosorption performance on mineralised leachate}

Table 3 summarises the efficacy of mineralised and oxidised leachate biosorption treatment. The very low $\mathrm{BOD}_{5}$ and COD concentrations of organic matter at the outlet indicated that all biodegradable organic matter had been removed. The $\mathrm{pH}$ adjustment was associated with the use of inorganic carbon during the nitrification phase by nitrifying autotrophic bacteria.

The leachate became transparent with a minimum turbidity value of $0.7 \mathrm{NTU}$, likely due to the double effect of biosorption: the adsorption and the nitrification of pollutants. The oxidation of the SM gave the yield of $71 \%$. This value improved with biosorption and reached the yield of $95.6 \%$. There was a slight increase in EC, which could be explained by the salt ion adsorption $(\mathrm{NaCl})$ present in the physiological water used to wash the biosorption. The column was washed in abundance with physiological and demineralized water to remove all the salts and metals 
Table 3 - Performance of treatment of oxidised leachate by biosorption

\begin{tabular}{|c|c|c|c|c|c|c|c|c|c|c|c|c|}
\hline $\begin{array}{c}\text { Characteristics of } \\
\text { leachate }\end{array}$ & $\mathrm{pH}$ & COD & $E C$ & Turbidity & SM & $\mathrm{NH}_{4}{ }^{+}$ & $\mathrm{NO}_{2}^{-}$ & $\mathrm{NO}_{3}^{-}$ & $\mathrm{PO}_{4}{ }^{3-}$ & $\mathrm{Ca}^{2+}$ & $\mathrm{Mg}^{2+}$ & $\mathrm{Fe}$ \\
\hline unit & - & $\mathrm{mg} \mathrm{O}_{2} \mathrm{I}^{-1}$ & $\mu \mathrm{S} \mathrm{cm}^{-1}$ & NTU & $\mathrm{mgl}^{-1}$ & $\mathrm{mgl}^{-1}$ & $\mathrm{mgl}^{-1}$ & $\mathrm{mgl}^{-1}$ & $\mathrm{mgl}^{-1}$ & $\mathrm{mgl}^{-1}$ & $\mathrm{mgl}^{-1}$ & $\mathrm{mgl}^{-1}$ \\
\hline $\begin{array}{l}\text { oxidised } \\
\text { leachate }\end{array}$ & 6.39 & 1933.8 & 0.024 & 53.3 & 235 & 1479 & 1.52 & 1300 & 5.04 & 1.64 & 27.94 & 3.25 \\
\hline biosorption effluent & 6.85 & 2.51 & 0.032 & 0.7 & 10.34 & 0.68 & 0.006 & 5.59 & 1.2 & 2.71 & 0.74 & 0.05 \\
\hline output $/ \%$ & & 99.87 & - & 98.73 & 95.6 & 99.95 & 99.96 & 99.57 & 78 & - & 97.35 & 98.2 \\
\hline
\end{tabular}

present in the components of the biomaterials. This technique has demonstrated an efficiency or no increase in the concentration of metals justified in other works by leaching the sludge used. ${ }^{18,54}$ Iron and other metals were also removed either by adsorption into pores of sawdust and activated coffee grounds or by the use of the bacterial sludge.

\section{Conclusion}

Relating to the characterization and treatment of the leachate from the TLC Aïn Defla, it can be concluded that these effluents are at neutral $\mathrm{pH} 8.8$ and have high content of organic matter (COD of $9669 \mathrm{mg} \mathrm{O}_{2} \mathrm{I}^{-1}, \mathrm{BOD}_{5}$ of 8875 $\mathrm{mg} \mathrm{O} \mathrm{O}^{-1}$ ) and suspended matter of $820 \mathrm{mg} \mathrm{l}^{-1}$. These contents greatly exceed the permitted chemical element contents of industrial effluents according to the Algerian standard. Analysis of the mineral fraction of the leachate showed a dominance of magnesium. The treatment of leachate by coupling oxidation and biosorption under optimal conditions $\left(45^{\circ} \mathrm{C}\right.$, $\mathrm{pH} 2.6$, with $\mathrm{H}_{2} \mathrm{O}_{2}$ volume fraction of $5 \%, \mathrm{H}_{2} \mathrm{O}_{2}$ concentration of $1.6 \mathrm{~mol} \mathrm{I}^{-1}, \mathrm{Fe}^{3+}$ concentration of $0.5 \mathrm{mmoll}^{-1}$, and the ratio $\left[\mathrm{H}_{2} \mathrm{O}_{2}\right] /\left[\mathrm{Fe}^{3+}\right]$ is 40 ) is an efficient treatment process with $\mathrm{BOD}_{5}$ reduction of $100 \%$ and COD reduction of $99 \%$. Removal of colloidal particles (SM) was up to $95.6 \%$. Reductions of phosphates, ammonium, sulphates, zinc, and iron were 78, 98, 96, 92, and $98.2 \%$, respectively. This methodology could be transposed to other national and international landfill sites with the same intrinsic and extrinsic characteristics.

\section{Conflict of interests}

The corresponding author states that there is no conflict of interest.

\section{ACKNOWLEDGEMENTS}

The authors would like to thank the staff of Technical Landfill Centre Aïn Defla, National Observatory for the Environment and Sustainable Development (ONEDD), and Laboratory of Chemistry 3 of Khemis Miliana University.

\section{References}

\section{Literatura}

1. B. Abd EL-Azziz, Journal Officiel de la République Algérienne (JORA) 75 (2009) 10-15.

2. G. Andreottola, Chemical and biological characteristics of landfill leachate CISA, Environmental sanitary engineering centre, via Marengo 34, I-09123 Cagliari, Italy, 1992, p. 68.

3. S. Renou, J. G. Givaudan, S. Poulain, F. Dirassouyan, P. Moulin, Landfill leachate treatment: Review and opportunity, J. Hazard. Mater. 150 (3) (2008) 468-493, doi: https://doi. org/10.1016/j.jhazmat.2007.09.077.

4. C. Öman, P. Hynning, Identification of organic compounds in municipal landfill leachates, J. Environ. Pollut. 80 (3) (1993) 265-271, doi: https://doi.org/10.1016/02697491(93)90047-r.

5. S. Fatima, S. K. Rafiq, A. Hai, Effect of depth and age on leachate characteristics of Achan Landfill, Srinagar, Jammu and Kashmir, India, J. Environ. Sci. Toxicol. Food Technol. (IOSR-JESTFT) 2 (2) (2012) 4-11, doi: https://doi. org/10.9790/2402-0220411.

6. Direction de l'Environnement de la Wilaya de Ain Defla, Direction du centre d'enfouissement technique Ain Defla, URL: https://rhinotenders.com/companies/company/dedirection-de-I-environnement-de-la-wilaya-de-ain-defla-q (19/12/2019).

7. P. Yao, Perspectives on technology for landfill leachate treatment, Arab. J. Chem. 10 (2) (2017) S2567-S2574, doi: https://doi.org/10.1016/j.arabjc.2013.09.031.

8. S. Smita Kumar, N. Bishnoi, Coagulation of landfill leachate by $\mathrm{FeCl}_{3}$ : Process optimization using Box-Behnken design (RSM), J. Appl. Water Sci. 7 (4) (2017) 1943-1953, doi: https://doi.org/10.1007/s13201-015-0372-1.

9. S. Xiao, J. Peng Y. Song, Degradation of biologically treated landfill leachate by using electrochemical process combined with UV irradiation, Sep. Purif. Technol. 117 (2013) 24-29, doi: https://doi.org/10.1016/j.seppur.2013.04.024.

10. A. Uygur, F. Kar, Biological nutrient removal from pre-treated landfill leachate in a sequencing batch reactor, J. Environ. Manage. 71 (2004) 9-14, doi: https://doi.org/10.1016/j.jenvman.2004.01.002.

11. A. Zouboulis, X. Chai, I. Katsoyiannis, The application of bioflocculant for the removal of humic acids from stabilized landfill leachates, J. Environ. Manage. 70 (2004) 35-41, doi: https://doi.org/10.1016/j.jenvman.2003.10.003.

12. W. Y. Ahn, S. K. Yim, G. T. Kim, S. H. Kim, Advanced land- 
fill leachate treatment using an integrated membrane process, Desalination 149 (2002) 109-114, doi: https://doi. org/10.1016/S0011-9164(02)00740-3.

13. J. Bohdziewicz, M. Bodzek, J. Górska, Application of pressure-driven membrane techniques to biological treatment of landfill leachate, Process Biochem. 36 (2001) 641-646, doi: https://doi.org/10.1016/S0032-9592(00)00259-4.

14. A. Anfruns, J. Gabarró, R. Gonzalez-Olmos, S. Puig, M. D. Balaguer, J. Colprim, Coupling anammox and advanced oxidation-based technologies for mature landfill leachate treatment, J. Hazard. Mater. 258-259 (2013) 27-34, doi: https:// doi.org/10.1016/j.jhazmat.2013.04.027.

15. R. Chemlal, L. Azzouz, R. Kernani, N. Abdi, H. Lounici, H. Grib, N. Mameri, N. Drouiche, Combination of advanced oxidation and biological processes for the landfill leachate treatment, Ecol. Eng. 73 (2014) 281-289, doi: https://doi. org/10.1016/j.ecoleng.2014.09.043.

16. S. H. Lin, C. C. Chang, Treatment of landfill leachate by combined electro-Fenton oxidation and sequencing batch reactor method, Water Res. 34 (2000) 4243-4249, doi: https:// doi.org/10.1016/S0043-1354(00)00185-8.

17. M. Zolfaghari, K. Jardak, P. Drogui, S. Kaur Brar, G. Buelna, R. Dubé, Landfill leachate treatment by sequential membrane bioreactor and electro-oxidation processes, J. Environ. Manage. 184 (2016) 318-326, doi: https://doi.org/10.1016/j. jenvman.2016.10.010.

18. O. Dia, Combinaison des procédés de biofiltration et d'électrocoagulation pour le traitement des lixiviatsdes sites d'enfouissement sanitaires, Thèse présentée pour l'obtention du grade de Philosophiaedoctor (Ph.D.) en sciences de l'eau Université du Québec Institut National de la Recherche Scientifique Centre Eau Terre Environnement, 2017.

19. M. T. Pérez, F. Torrades, X. Domènech, J. Peral, Fenton and photofenton oxidation of textiles effluents, Water Res. 36 (2002) 2703-2710, doi: https://doi.org/10.1016/S00431354(01)00506-1.

20. S. Dalhatou, Application des techniques d'oxydation avancée pour la dépollution des effluents organiques dans les eaux de rejets industriels: cas des savonneries. Thèse pour l'obtention du diplôme docteur /PhD de l'université de YAOUNDE I, 2014, Français.

21. G. Centi, S. Perathoner, G. Romeo, 31-O-03-Fe/MFI as a new heterogeneous Fenton-type catalyst in the treatment of wastewater from agroindustrial processes, Stud. Surf. Sci. Catal. 135 (2001) 181, doi: https://doi.org/10.1016/S01672991(01)81339-2.

22. K. Barbusinski, Fenton reaction, controversy concerning the chemistry, Ecol.Chem. Eng. 16 (3) (2009) 347-358, url: http://tchie.uni.opole.pl/freeECE/S_16_3/Barbusinski_16(3). pdf.

23. Md. Z. Alam, E. S. Ameem, S. A. Muyibi, N. A. Kabbashi, The factors affecting the performance of activated carbon prepared from oil palm empty fruit bunches for adsorption of phenol, Chem. Eng. J. 155 (1-2) (2009) 191-198, doi: https://doi.org/10.1016/j.proeng.2016.06.610.

24. R. Subha, C. Namasivayam, Kinetics and isotherm studies for the adsorption of phenol using low cost micro porous $\mathrm{ZnCl}_{2}$ activated coir pith carbon, Canad. J. Civil Eng. 36 (1) (2009) 148-159, doi: https://doi.org/10.1139/S08-039.

25. V. Bello-Huitle, P. Atenco-Fernandez, R. Reyes-Mazzoco, Adsorption studies of methylene blue and phenol onto pecan and castile nutshells prepared by chemical activation, Rev. Mex. Ing. Quim. 9 (3) (2010) 313-322, url: http://www.scielo.org.mx/pdf/rmiq/v9n3/v9n3a6.pdf.

26. J. Seema, J. V. Radha, Adsorption of phenol and substituted chlorophenols from aqueous solution by acti- vated carbon prepared from jackfruit (artocarpusheterophyllus) peel-kinetics and equilibrium studies, Sep. Sci. Technol. 42 (9) (2007) 2019-2032, doi: https://doi. org/10.1080/15275920701313608.

27. S. Timur, I. C. Kantarli, S. Onenc, J. Yanik Characterization and application of activated carbon produced from oak cups pulp, J. Anal. Appl. Pyrol. 89 (1) (2010) 129-136, doi: https://doi.org/10.1016/j.jaap.2010.07.002.

28. S. Rengaraj, R. Sivabalan, B. Arabindoo, V. Murugesan, Adsorption kinetics of $O$-cresol on activated carbon from palm seed coat, Ind. J. Chem. Technol. 7 (3) (2000) 127-131, url: https://squ.pure.elsevier.com/en/publications/adsorption-kinetics-of-o-cresol-on-activated-carbon-from-palm-see.

29. M. Ahmaruzzaman D. K. Sharma, Adsorption of phenols from wastewater, J. Coll. Interf. Sci. 287 (1) (2005) 14-24, doi: https://doi.org/10.1016/j.jcis.2005.01.075.

30. R. Dhawan, S. Kumar, A. Kaur, M. K. Choudhary, Activated carbons as potential adsorbents for removal of organic pollutants from water/wastewater, Int. J. Innov. Res. Sci. Eng. Technol. 3 (2017).

31. K. H. Kang, H. S. Shin, H. Park, Characterization of humic substances present in landfill leachates with different landfill ages and its implications, Water Res. 36 (2002) 4023-4032, doi: https://doi.org/10.1016/s0043-1354(02)00114-8.

32. D. Kulikowska, E. Klimiuk, The effect of landfill age on municipal leachate composition, Biores. Technol. 99 (2008) 59815985, https://doi.org/10.1016/j.biortech.2007.10.015.

33. Institut de Veille Sanitaire, Stockage des Déchets et santé publique. Synthèse et recommandation. Rapport rédigé à la demande des ministères respectivement chargés de l'environnement et de la santé Françaises, 2004.

34. J. E .Chang, Treatment of landfill leachate with an upflow anaerobic reactor combining a sludge bed and a filter, Water. Sci. Technol. 21 (1989) 133-143, doi: https://doi. org/10.2166/wst.1989.0217.

35. H. Khattabi, Intérêt de l'étude des paramètres hydrogéologiques et hydro biologiques pour la compréhension du fonctionnement de la station de traitement des lixiviats de la décharge d'ordures ménagères (Belfort, France). Thèse de doctorat, Institut des sciences de l'environnement, France, 2002, p. 167.

36. S. Trabelsi, Etudes de traitement des lixiviats des déchets urbains par les procédés d'oxydation avancée photochimiques et électrochimiques: application aux lixiviats de la décharge tunisienne "JebelChakir" , thèse pour obtenir le grade de docteur de I'université Paris-Est et Institut national des sciences appliquées et de technologie, 2012, France.

37. T. Bennama, A. Adebab, Z. Derriche, Physico-chemical and bacteriological characterization of leaches from the public discharge of EL-KERMA, International Conference "EARTH and WATER", Annaba, November 21, 22 \& 23, 2004.

38. F. J. Benitez, J. L. Acero, F. J. Real, F. J. Rubio, A. I. Leal, The role of hydroxyl radicals for the decomposition of $p$-hydroxyphenylacetic acid in aqueous solutions, Water Res. 35 (2001) 1338-1343, doi: https://doi.org/10.1016/S00431354(00)00364-X.

39. E. Neyen, J. Baeyens, A review of classic Fenton's peroxidation as an advanced oxidation technique, J. Hazard. Mater. 98 (2003) 33-50, doi: https://doi.org/10.1016/S03043894(02)00282-0.

40. S. Trabelsi, N. Oturan, N. Bellakhal, M. A. Oturan, Application of the photo-Fenton process to the mineralization of phthalic anhydride in aqueous medium, Desalin. Water Treat. 25 (2011) 210-215, doi: https://doi.org/10.5004/ dwt.2011.1445. 
41. M. Tokumura, H. T. Znad, Y. Kawase, Decolorization of dark brown colored coffee effluent by solar photo-Fenton reaction: Effect of solar light dose on decolorization kinetics, Water Res. 42 (2008) 4665-4673, doi: https://doi. org/10.1016/j.watres.2008.08.007.

42. F. Bouhezila, M. Hariti, H. Lounici, N. Hameri., Treatment of the OUED SMAR town landfill leachate by an electrochemical reactor, Desalination 280 (2011) 347-353, doi: https:// doi.org/10.1016/j.desal.2011.07.032.

43. F. Ilhan, U. Kart, O. Apaydin, M. T. Gonullu, Treatment of leachate by electrocoagulation using aluminum and iron electrodes, J. Hazard. Mater. 154 (2008) 381-389, doi: https:// doi.org/10.1016/j.jhazmat.2007.10.035.

44. M. Poveda, Q. Yuan, J. Oleszkiewicz, The Effectiveness of Pretreatment Methods on COD and Ammonia Removal from Landfill Leachate, Int. J. Environ. Sci. Develop. 7 (2016) 257, doi: https://doi.org/10.7763/IJESD.2016.V7.780.

45. P. Drogui, J. F. Blais, G. Mercier, Review of electrochemical technologies for environmental applications, Rec. Pat. Eng. 1 (2007) 257-272, doi: https://doi. org/10.2174/187221207782411629.

46. V. Kavitha, K. Palanivelu, The Role of Ferrous Ion in Fenton and Photo-Fenton Processes for the Degradation of Phenol, Chemosphere 55 (2004) 1235-1243, doi: https://doi. org/10.1016/j.chemosphere.2003.12.022.

47. L. Z. Ping, W. W. Hui, S. Ping, G. J. Song, C. Jin, Characterization of dissolved organic matter in landfill leachate during the combined treatment process of air stripping, Fenton, SBR and coagulation, Waste Manage. 41 (2015) 111-118, doi: https://doi.org/10.1016/J.WASMAN.2015.03.044.

48. T. X. Huong Le, B. Alemán, J. J. Vilatela, M. Bechelany, M.
Cretin, Removal of Acid Orange 7 from water by electrochemically generated Fenton's reagent, J. Hazard. Mater. 163 (2009) 1213-1220, doi: https://doi.org/10.3389/ fmats.2018.00009.

49. S.-L. Huo, B. D. Xi, H. C. Yu, H. L. Liu, Dissolved organic matter in leachate from different treatment processes, Water Environ. J. 23 (2009) 15-22, doi: https://doi.org/10.1111/ j.1747-6593.2007.00104.x.

50. M. Garzón-Zúñiga, P. Lassard, G. Aabry, G. Buelna, Nitrogen elimination mechanisms in an organic media aerated biofilter treating pig manure, Environ. Technol. 26 (2005) 361372, doi: https://doi.org/10.1080/09593332608618552.

51. V. Iversen, H. Koseoglu, N. O. Yigit, A. Drew, M. Kitis, B. Lesjean, M. Kraume, Impacts of membrane flux enhancers on activated sludge respiration and nutrient removal in MBRs, Water Res. 43 (2009) 822-830, doi: https://doi. org/10.1016/j.watres.2008.11.022.

52. E. J. Lees, B. Noble, R. Hewitt, S. A. Parsons, The Impact of Residual Coagulant on the Respiration Rate and Sludge Characteristics of an Activated Microbial Biomass, Proc. Saf. Environ. Prot. 79 (2001) 283-290, doi: https://doi. org/10.1205/095758201753189721.

53. B. Koukal, É. Guéguen, M. Pardos, J. Dominik, Influence of humic substances on the toxic effects of cadmium and zinc to the green alga Pseudokirchneriella subcapitata, Chemosphere 53 (2003) 953-961, doi: https://doi. org/10.1016/S0045-6535(03)00720-3.

54. E. Tipping, Humic Ion-Binding Model VI: An Improved Description of the Interactions of Protons and Metal lons with Humic Substances, Aquat. Geochem. 4 (1998) 3-47, doi: https://doi.org/10.1023/A:1009627214459. 


\section{SAŽETAK}

\section{Obrada procjednih voda iz odlagališta otpada Aïn Defla (Alžir) procesom oksidacije i biosorpcije \\ Brahim Feraoun, ${ }^{a,}{ }^{*}$ Abd-Elmouneïm Belhadj, ${ }^{\text {K Khaled Otmanine }}{ }^{\mathrm{b}}$ i Mounir Hammoudic}

Tema ovog istraživanja je obrada procjednih voda odlagališta otpada Aïn Defla u Alžiru, koje predstavljaju ozbiljnu prijetnju po okoliš. Ispitivano je uklanjanje organskih tvari (izraženo preko kemijske potrošnje kisika (KPK) i biološke potrošnje kisika $\left(\mathrm{BPK}_{5}\right)$ ), suspendiranih čestica (SČ), mineralnih tvari (fosfati i amonijačni dušik) i teških metala (cink i željezo) iz procjednih voda kombiniranjem procesa oksidacije i biosorpcije. Rezultati analiza pokazali su da je pH-vrijednost procjedne vode iznosila 8,8 te da je bila izrazito opterećena organskom tvari (zamućenje $=553 \mathrm{NTU}$, $\mathrm{SC}=820 \mathrm{mgl}^{-1} ; \mathrm{KPK}=9669 \mathrm{mg} \mathrm{O}_{2} \mathrm{I}^{-1}$, te $\left.\mathrm{BPK}_{5}=8875 \mathrm{mg} \mathrm{O}_{2} \mathrm{I}^{-1}\right)$, u solima $\left(E C=19,4 \mathrm{mS} \mathrm{cm}^{-1}\right)$, amonijačnim dušikom (2027 $\left.\mathrm{mgl}^{-1}\right)$, fosfatima $\left(22,9 \mathrm{mgl}^{-1}\right)$ i sulfatima $\left(750 \mathrm{mg} \mathrm{l}^{-1}\right)$. Također sadržavala je i značajne količine teških metala, osobito cinka $\left(4,21 \mathrm{mg} \mathrm{I}^{-1}\right)$ i željeza $\left(47,5 \mathrm{mg} \mathrm{I}^{-1}\right)$. Iz fizikalno-kemijskih parametara praćenih tijekom obrade vidljivo je, pri optimalnim uvjetima $\left(45^{\circ} \mathrm{C},\left[\mathrm{H}_{2} \mathrm{O}_{2}\right]=1,6 \mathrm{moll}^{-1}\right)$, volumni udio $\left.\varphi\left(\mathrm{H}_{2} \mathrm{O}_{2}\right)=5 \% \mathrm{i}\left[\mathrm{Fe}^{3+}\right]=0,5 \mathrm{mmol} \mathrm{I}^{-1}\right)$, smanjenje

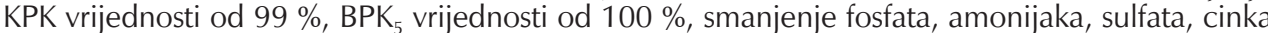
i željeza za $78 \%$, 98 \%, $96 \%$, $92 \%$, odnosno $98 \%$. Također, 95,6\% suspendiranih čestica uklonjeno je tijekom obrade procjedne vode.

\section{Ključne riječi}

Procjedne vode, odlagalište, proces oksidacije, biosorpcija

${ }^{a}$ Biomaterials and Transport Phenomena Laboratory (LBMPT), Yahia Fares University, Department of Chemical Engineering and Environment, Médéa, 26000, Alžir

${ }^{\mathrm{b}}$ Bioressources Naturelles Locales LBRN, Hassiba Benbouali University of Chlef, Faculty of Technology, Department of Process Engineering, Chlef, Alžir

' Biomaterials and Transport Phenomena Laboratory (LBMPT), Yahia Fares University, Department of

Chemical Engineering and Environment, Experimental Biology and Pharmacology Team, Médéa, 26 000, Alžir
Izvorni znanstveni rad Prispjelo 22. studenoga 2020. Prihvaćeno 6. travnja 2021. 